\title{
FACTORS AFFECTING LIQUIDITY RISK- AN EMPIRICAL ANALYSIS ON TURKISH BANKING SECTOR
}

\section{LİKİDITTE RISSKINİ ETKİLEYEN FAKTÖRLER-TÜRK BANKACILIK SEKTÖRÜ ÜZERINE BİR ANALİZ*}

\author{
Bade EKIMM KOCAMAN ${ }^{1}$, Şenol BABUŞCU², Adalet HAZAR ${ }^{3}$
}
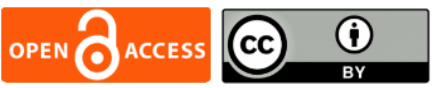

1. Arș. Gör., Başkent Üniversitesi, Finans ve Bankacılık Bölümü, badeekim@ hotmail.com, https://orcid.org/0000-0002-8967-3935

2. Prof. Dr., Başkent Üniversitesi, Finans ve Bankacılık Bölümü, babuscu@baskent.edu.tr, https://orcid.org/0000-0003-2870-6358

3. Prof. Dr., Başkent Üniversitesi, Finans ve Bankacılık Bölümü, adalethazar@gmail.com, https://orcid.org/0000-0002-1483-8360

\begin{tabular}{|c|c|}
\hline Makale Türü & Article Type \\
\hline Makale Türü... & Choose Type... \\
\hline Başvuru Tarihi & Application Date \\
\hline 06.08 .2021 & 08.06 .2021 \\
\hline Yayına Kabul Tarihi & Admission Date \\
\hline 13.10 .2021 & 10.13 .2021 \\
\hline
\end{tabular}

* Çalışma, 22.Finans Sempozyumu'nda 10-13 Ekim 2018 tarihlerinde sunulmuştur.

\section{Abstract}

The aim of this study is to determine the factors affecting the liquidity risk of deposit banks in Turkey. In this context, 10 deposit banks with the highest asset size according to their 2020 end of year financial tables were included to the sample and the quarterly data for the 2010-2020 period were tested by static panel data analysis. According to the model results, it is determined that "Equity / Total Assets", "Money Market Funds/Total Assets" and "Inflation" variables affect the liquidity risk. It is also important and specific for the study that the "Money Market Funds/Total Assets" ratio is a determining factor in the liquidity risk, in terms of the literature contribution of the study.

Keywords: Liquidity Risk, Panel Data Analysis, Banking Sector.

$\ddot{O} z$

Bu çalışmanın amacı, Türkiye'deki mevduat bankalarının likidite riskini etkileyen faktörlerin belirlenmesidir. Bu kapsamda, 2020 y1l sonu finansal verilerine göre aktif büyüklüğü en yüksek olan 10 mevduat bankası inceleme kapsamına alınmıs ve 20102020 yılları arasında çeyreklik dönem verileri statik panel veri analizi ile test edilmiştir. Model sonuçlarına göre "Özkaynaklar/Toplam Aktif”, "Para Piyasalarına Borçlar/Toplam Aktif" ve "Enflasyon" değişkenlerinin likidite riskini etkilediği belirlenmiștir. Aynı zamanda çalıșma sonucunda likidite riskini belirleyen faktörlerden biri olarak Para Piyasasına Borçlar/Toplam Aktif rasyosunun tespit edilmesinin literatüre katkı anlamında önemli olduğu düşünülmektedir.

Anahtar Kelimeler: Likidite Riski, Panel Veri Analizi, Bankacılık Sektörü. 


\section{Çalışmanın Amacı}

\section{GENIŞLETILMIŞ ÖZET}

Bu makale, Türkiye'deki mevduat bankalarının likidite riskini etkileyen faktörleri panel veri analizi kullanarak analiz etmeyi amaçlamaktadır.

\section{Araştırma Soruları}

“Para Piyasalarına Borçlar/Toplam Aktif” değişkeni ile likidite riski arasında ilişki var mıdır? “Gerçeğe Uygun Değer Farkı Kar Zarar’a Yansıtılan Finansal Varlıklar/Toplam Aktif” değişkeni ile likidite riski arasında ilişki var mıdır?

\section{Literatür Araştırması}

Bankacılık sektöründe likidite riski yönetimi kapsamında farklı bakış açılarıyla ele alınmış birçok çalışma bulunmaktadır. Bu tür çalışmaların büyük bir kısmı likidite riskini belirleyen faktörler üzerinde odaklanmıştır. Çalışmalarda yöntem olarak genellikle panel veri analizi kullanılmıştır. Çalışmaların çoğunluğu öz kaynaklar, aktif büyüklük, mevduat düzeyi, donuk alacaklar gibi bankalara özgü faktörlerin yanı sıra enflasyon, faiz, GSYİH gibi makroekonomik değişkenlerin de likidite riski üzerindeki etkisini incelemektedir. Bahsi geçen faktörlerin likidite riski üzerindeki etkisi yönünden örtüşen çalışmalar olmakla birlikte literatürde net bir görüş bulunmamaktadır. Yabancı literatürde likidite riskini etkileyen faktörler ile ilgili çalışmalar 2001 yılından itibaren yoğunluk kazanmakla birlikte yerli yazında konuya ilişkin çalışmalar 2012 yılında başlamaktadır.

\section{Yöntem}

Çalışmada kullanılan yöntem statik panel veri analizidir. Panel veri analizine başlamadan önce değişkenlerin durağan olup olmadığı tespit edilmelidir. Ekonomik ve finansal değişkenler trend veya mevsimsellik içerdiğinde durağanlık prensibi ihlal edilebilmektedir (Yurdakul, 2003). Analizde kullanılan değişkenlerin durağan olmaması halinde ekonometrik modeller yanıltıcı sonuçlar verebilmektedir. Durağan olmayan değişken seti ile yapılan analizlerde sahte regresyon durumu ile karşı karşıya kalınabilir. $\mathrm{Bu}$ nedenle, panel veri analizlerinde, serilere birim kök (unit root) testi uygulanmaktadır. Çalışmada da değişkenlerin durağanlığına yönelik gerekli testler uygulandıktan sonra veri setinin panel veri analizine uygun olup olmadığ model üzerinden analiz yapılmıştır.

\section{Sonuç ve Değerlendirme}

İlk olarak, Öz kaynaklar/Toplam Aktif değişkeni ile likidite riskini ölçmekte kullanılan Likit Aktifler/Kısa Vadeli Yükümlülükler rasyosu arasında pozitif bir ilişki bulunmuştur. Bu nedenle, Türkiye'deki mevduat bankalarının likidite riskine maruz kalma olasılıklarını azaltabilmek için öz kaynak yapılarını güçlendirmeleri önerilmektedir. İkinci olarak, Para Piyasalarına Borçlar/Toplam Aktif ile Likit Aktifler/Kısa Vadeli Yükümlülükler rasyosu arasında pozitif bir ilişki olduğu sonucuna varılmıştır. Bankaların para piyasalarından ilave likidite temin edebilme potansiyelleri likidite riskini azaltıcı yönde etki yapmaktadır. Son olarak, bankacılık sektörünün ekonomideki makroekonomik 
faktörlerden etkilendiği göz önüne alındığında, enflasyon artışının genel makroekonomik denge yarattığı olumsuz etkiler bankaların karşı karşıya kalabileceği likidite riskini de artıcı bir etki yaratmaktadır. Sonuç olarak, bankaların bu faktörleri dikkate alarak likidite riskini doğru yönetmelerinin optimum likidite düzeyine ulaşarak karlılıklarına olumlu yönde katkı sağlayacakları tahmin edilmektedir. 


\section{INTRODUCTION}

Banks, which are one of the most important actors of the country's economy and especially the financial sector, play a vital role in transferring savings into investments. Due to the developments in the finance sector, increase in product and customer diversity, the spread of derivative products, and increased competition banks' risky investments increase simultaneously. Banks with increased risk are more likely to face with problems. In banking sector, because of the contagion effect it is possible that a crisis in one bank can spread to other banks. Finally, a crisis in banking sector may affect the whole economy systematically.

Banking is art of managing risk. Banks are exposed to numerous kind of risks due to their activities. Liquidity risk, which is one of the sub-components of market risk, is an important risk type that can lead banks to bankruptcy. Therefore, management of liquidity risk is vital to ensure the continuity of banks.

Despite large number of studies in the foreign literature about banks' liquidity risk, there is limited number of studies in the Turkish Banking Sector. Accordingly, lack of studies played an important role in the emergence of our study. In this context, the aim of the study is to investigate the factors that determine the liquidity risk of deposit banks operating in Turkey. We tried to determine the factors affecting liquidity risk in micro and macro levels by including top 10 banks according to asset size in the Turkish banking sector.

\section{LIQUIDITY CONCEPT IN BANKING}

In general terms, liquidity is the solvency of the debts that are due. In terms of banking, it can be defined as the ability to transform assets into cash without loss (Candan and Özün, 2009).

\subsection{Liquidity Requirement Estimation}

It is important for banks to be able to estimate the liquidity they need, both for the effectiveness of central banks' monetary policies and for banks that are parties to central bank transactions to carry out smooth banking transactions (Reddy, 2002).

The daily liquidity level of banks is mainly; the balance of demand deposits, the amount of liabilities that have expired but not requested from the bank, the amount of liabilities due, the amount required for the allocated loans, the amount required to meet the legal obligations. However, banks do not keep enough cash to meet the required amount for daily liquidity needs. Because term and demand deposits are not immediately withdrawn from the bank, the credit limits are not used by all customers at the same time, the overdue deposits are renewed, new deposits and foreign source comes to bank meeting possible withdrawals, banks do not need to keep high-level cash. Therefore, banks have to estimate the level of liquidity to continue their activities (Altintas, 2018). 


\subsection{Regulations Regarding Liquidity in the Turkish Banking System}

\subsubsection{Regulation on Measurement and Evaluation of Liquidity Adequacy of Banks}

Liquidity Adequacy is regulated in banking law no. 5411. It is stated that "Banks shall calculate, achieve, perpetuate and report the minimum liquidity level in accordance with the principles and procedures to be set by the Board upon the approval of the Central Bank." As the article shows, it is by law for banks operating in Turkey to measure and manage their liquidity competencies and liquidity risk.

"Banking Regulation and Supervision Agency (BRSA)" published on November 1, 2006, the "Regulation on Measurement and Evaluation of Liquidity Adequacy of Banks" on the basis of the article. Due to the regulation published in 2006, slices of terms are stated to calculate total and foreign currency liquidity adequacy ratios.

Table 1. Slices of Terms

\begin{tabular}{|c|c|}
\hline Slices of terms & Period before term \\
\hline First slice of term & "0 to 7 days" \\
\hline Second slice of term & "0 to 31 days" \\
\hline
\end{tabular}

Minimum liquidity adequacy ratios;

"The total liquidity adequacy ratio concerning the second slice of terms on the basis of the weekly simple arithmetical average of the total liquidity adequacy ratios related to the first slice of terms may not be less than $100 \%$."

"The foreign currency adequacy ratio concerning the second slice of terms on the basis of the weekly simple arithmetical average of the foreign currency liquidity adequacy ratio related to the first slice of terms may not be less than $80 \%$."

Non-compliance with the proportional limits;

"Non-compliance may not take place over the ratios concerning the second slice of terms twice in a row within a calendar year."

"It is obligatory to eliminate any noncompliance that may occur relating to the first slice of term within the next two weeks. No more than six instances of non-compliance may be realized over the ratios concerning the first slice of terms within a calendar year including any instances of non-compliance rectified."

\subsubsection{Regulation on Calculation of Liquidity Coverage Ratio of Banks}

In Turkey, liquidity regulations are made in parallel with Basel III regulations. "Banking Regulation and Supervision Agency (BRSA)" published on March 21, 2014, the "Regulation on Calculation of Liquidity Coverage Ratio of Banks" to set down the procedures and principles regarding banks' having high quality liquid assets stock at a sufficient level to cover their net cash outflows in order to designate minimum liquidity level, both at consolidated level and on individual basis. According to regulation liquidity level of banks should be measured by calculating liquidity coverage 
ratio on consolidated and individual level in Turkish Lira and FX total and consolidated and individual level in FX.

\subsection{Basel 3 Liquidity Ratios}

After the financial crisis that affected the entire world in 2008, the importance of liquidity for the banking sector and therefore financial markets was once again understood. Before the crisis asset markets were alive and funding costs were low but the rapid change in market conditions has shown how quickly liquidity can decrease in the markets. Although banks provided minimum capital adequacy rates during the crisis, due to liquidity problems they were at risk of bankruptcy.

Although indicators such as credit/deposit ratio are used to measure funding risks and monitor banks' liquidity positions, these indicators have been insufficient for a comprehensive risk assessment due to their disregard for stable funding sources other than deposits and the failure to take into account the maturity structure of asset-liabilities.

Therefore, after the global crisis "Basel Committee on Banking Supervision (BCBS)" published principles to strengthen the liquidity management of banks and developed minimum liquidity rates for the first time. In this context, 2 different liquidity ratios introduced with Basel 3.

\subsubsection{Liquidity Coverage Ratio}

The aim of this rate is to hold up banks for 1 month with the support of the central bank. In other words, the "Liquidity Coverage Ratio" aims to ensure banks have enough stock of high-quality liquid assets to cover net cash outflows within 30 days.

$$
L C R=\frac{\text { Total stock of high quality liquid assets }}{\text { Total net cash outflows over the next } 30 \text { calendar days }} \geq \% 100
$$

LCR requires banks to keep $25 \%$ of their cash inflows in liquid form or invest them in high liquidity assets. In case of liquidity risk, banks can provide liquidity by giving these assets to central bank.

In Basel 3, the LCR is required to be implemented as of 01.01.2015. "Banking Regulation and Supervision Agency (BRSA)" started to implement LCR in Turkey with the regulation dated March 21, 2014 as mentioned above, and aimed to reach minimum rates on 01 January 2019.

\subsubsection{Net Stable Funding Ratio}

"Net Stable Funding Rate (NSFR)" is calculated by comparing the current stable (long-term or long-term accepted) equity and foreign resources in the passive to the assets that are expected to be funded with stable resources.

$$
N S F R=\frac{\text { Total Available Stable Funding }}{\text { Total Required Stable Funding }} \geq \% 100
$$


NSFR is developed for long-term liquidity risk. In this respect, it is a complementary liquidity ratio to the LCR, which measures resilience to short-term liquidity shocks. NSFR provides comprehensive measurement of liquidity risk by taking into account the maturity match between assets and liabilities.

The Basel Committee published the final regulation on NSFR on 31 October 2014. "Banking Regulation and Supervision Agency (BRSA)" published the draft of "Regulation on Banks' Net Stable Funding Rate Calculation" in 2018/January.

\subsection{Liquidity Risk and Circumstances That Pose Liquidity Risk}

Liquidity risk is insufficient cash for the bank's normal operations that is, the bank does not have sufficient cash availability and the ability to generate cash to meet its obligations at maturity (Altıntaş, 2006).

The risk of the bank's failure to meet its obligations in time is the risk of funding liquidity, and the bank's inability to convert its positions in time and from a reasonable price to ash is the risk of market liquidity.

These 2 types of liquidity risks are defined in the "Guideline for Liquidity Risk Management" published by BSRA on 31/03/2016.

"Funding liquidity risk: The risk that the bank may fail to meet the liability and debts without becoming overdue and incurring any contingency losses."

"Market Liquidity Risk: The risk that the bank may fail to sale or close a position without effecting the market value because of inadequate market depth or decay of market conditions or the risk that a market price does not occur for some reason."

Situations that pose liquidity risk are classified in five main headings (Şakar, 2002)

- Maturity mismatch,

- Decrease of asset quality

- Unexpected deposit flows

- Decrease in profitability

- Crises

\section{RELATED LITERATURE}

There are several academic studies in banking sector from different perspectives on liquidity risk management. Significant part of these studies focused on factors that determine liquidity risk. As it is scope of our study, studies on determinants of liquidity risk are included in this section.

Shen et al. (2001) using Taiwan's banking sector data between 1993 and 1999, found that high liquid assets/deposit ratio is negatively correlated with liquidity risk. 
Berger and Bouwman (2006), examined factors that determined the liquidity risk of American banks for 1993-2003. Using panel data analysis, positive relationship between bank size and liquidity risk was determined. Banks with high asset sizes were found to be exposed to greater liquidity risks.

Dinger (2009) tried to identify factors affecting liquidity risk of 10 developing European countries over a 10-year period from 1994 to 2004. Capital adequacy ratio and real GDP growth is negatively correlated with liquidity risk. On the other hand, foreign-controlled banks tend to hold less liquidity than smaller banks in eastern Europe because they have access to resources from the bank in the main country.

A study conducted by Vodova (2011) investigated factors affecting the liquidity risk of commercial banks operating in the Czech Republic period between 2001 and 2009. The author found that capital adequacy rate and loan interest rate is negatively correlated with liquidity risk. In contrast, 2008 crisis and inflation positively affect liquidity risk. The bank size has irrelevant relation with liquidity risk.

Akhtar et al. (2011) analyzed the factors affecting liquidity risk sample of 12 trading and participation banks operating in the Pakistan banking sector. The study concluded that there is a positive and significant correlation between return on assets (ROA), asset size and liquidity risk. In contrast, return on equity (ROE) and capital adequacy ratio negatively affect liquidity risk.

Munteanu (2012) examined the factors affecting the liquidity of commercial banks operating in Romania with multivariate regression analysis. Two different type dependent variables were used in the analysis and the variables were categorized as internal and external factors. Using a panel of 27 banks over the period of 2002-2010, the crisis period was taken into account. In the crisis period model, significant impact of Z-score variable on bank liquidity was identified.

Laurine (2013) researched factors affecting the liquidity risk of commercial banks in Zimbabwe for a period of 3 years. It was only taken into account between 2009 and 2012 since Zimbabwe's exchange rate regime changed. The study concluded that balance sheet total and default loans had positive effect while capital adequacy ratio, interest margin, reserve requirement ratio and inflation rate negatively affected liquidity risk.

Moussa (2015) covering 18 banks in Tunisia for 2000-2010 period, investigated the relationship between liquidity risk and internal, external factors. The analysis found that financial performance, capital, operating costs, GDP, inflation, delayed liquidity have significant impact on bank liquidity. On the other hand, size, loans ratio, financial costs/ total credits, deposit ratio do not have a significant impact on bank liquidity. 
Singh and Sharma (2016) showed that liquidity risk for 59 banks in India was positively correlated with asset size and economic growth, but negatively correlated with return on assets, deposit level and inflation rate.

Sopan and Dutta (2018) studied data from 45 banks operating in India's banking sector between 2005 and 2016. The study found positive relation of bank size, profitability rates and inflation rate with liquidity risk. Whereas GDP has no significant impact on the liquidity risk of Tunisian banks.

Ahamed (2021) conducted regression analysis with panel data set of 23 commercial banks operating in Bangladesh between 2005 and 2018. The empirical analysis found that bank size negatively affects liquidity risk. On the other hand, inflation is negatively and GDP is positively related with liquidity risk within macroeconomic variables.

Studies on determinants of liquidity risk in domestic literature starts by 2012 .

Çelik and Akarım (2012) used panel data analysis for the period 1998-2008 to investigate factors affecting liquidity risk of 9 banks listed on Stock Exchange. Results showed that return on equity (ROE) negatively affect liquidity risk, whereas external financing and return on assets (ROA) are positively correlated with liquidity risk.

Ayaydın and Karaaslan (2014) included 23 banks and analyzed bank-specific variables, impact of 2008 financial crisis and macroeconomic indicators on liquidity risk between 2003 and 2011. Foreign banks found to be exposed to more liquidity risks than other banks.

Iş1 and Özkan (2015) studied determinants of the liquidity risk using quarterly data from 2006 to 2014 with 4 participation banks in Turkey. Using unrelated regression model, previous period liquidity risk and credit expansion variables are significant and there is a positive relationship in the disclosure of liquidity risk.

Using a sample of Turkish banking sector for the period 2005-2014, Zengin and Yüksel (2016) argued that liquidity risk is negatively related to capital adequacy ratio but positively related to net interest margin. Consequently, in case of lower capital adequacy and higher net interest margin banks are exposed to more liquidity risk.

Iş1k and Belke (2017) conducted a research for the period 2006-2015 banks trading in BİST Stock Exchange. The results showed that variables such as return on equity (ROE), capital, deposit growth, loan losses and inflation rate are negatively correlated with liquidity risk, whereas bank size and economic growth are positively correlated with liquidity risk.

Firuzan and Firuzan (2017) covering 16 deposit banks and using data from 2009 to 2016 tried to determine factors affecting liquidity and credit risk. Dynamic panel data analysis on liquidity risk is 
applied, and concluded that fluctuations in macroeconomic variables affect the amount of capital of banks and have an impact on liquidity risk.

Ersoy and Aydin (2018) identified factors affecting the liquidity level of banks covering quarterly data of 27 banks between 2005 and 2015. Because the data set included global crisis years dummy variable was used. As a result of the analysis, capital, asset quality and deposit level is positively correlated with liquid assets. However, between bank size and liquidity level a nonlinear relationship in the form of inverted $\mathrm{U}$-shape is shown. In addition, in terms of macroeconomic factors economic growth, unemployment rate and global crisis variables negatively affect banks' liquidity level.

Erdem et al. (2018) used two-stage cluster analysis gathering annual data of 23 commercial banks between 2008 and 2018 to determine the liquidity risk level. As a result of the clustering analysis, banks were divided into two clusters and 19 banks were in the first cluster and 4 in the second cluster. It is determined that the most important variable in dividing banks into two clusters is the ratio of liquid assets/total assets. Other variables with importance level above 50\% are total loans/total assets, capital adequacy ratio, equity/total assets ratio.

Çanakçı and Tunalı (2018) investigated the studies in the literature and examined liquidity risk factors of participation banks. As a result of the evaluations bank-specific factors are important indicator and have different empirical consequences in terms of their impact on liquidity risk.

\section{DATA AND METODOLOGY}

\subsection{Data}

By June 2021, the number of actively operating banks in the Turkish banking system is 53 . The number of deposit banks is 32 , the number of development and investment banks is 15 , the number of participation banks is 6. In addition, number of banks under the Deposit Insurance Fund is 2. In our study, top 10 deposit banks in terms of asset total operating in Turkey between 2010 and 2020 are included in the analysis. Because of their different characteristics participation and development/investment banks are excluded from the sample.

Table 2. Banks Included in the Analysis

\begin{tabular}{|c|c|c|}
\hline Bank Name & $\begin{array}{l}\text { Asset Total } \\
\text { (million TL) }\end{array}$ & $\begin{array}{c}\text { Share from the Sector } \\
(\%)\end{array}$ \\
\hline "Türkiye Cumhuriyeti Ziraat Bankası A.Ş." & 942,601 & 16.6 \\
\hline "Türkive Vakıflar Bankası T.A.O." & 698,897 & 12.3 \\
\hline "Türkiye Halk Bankası A.Ș." & 680,026 & 12.0 \\
\hline "Türkiye İş Bankası A.Ș." & 593,902 & 10.5 \\
\hline "Türkiye Garanti Bankası A.Ş." & 492,798 & 8.7 \\
\hline "Yapı ve Kredi Bankası A.Ș." & 459,694 & 8.1 \\
\hline "Akbank T.A.SS."” & 446,101 & 7.9 \\
\hline "QNB Finansbank A.Ș." & 227,253 & 4.0 \\
\hline "Denizbank A.Ş." & 199,256 & 3.5 \\
\hline
\end{tabular}




\begin{tabular}{|l|c|c|}
\hline "Türk Ekonomi Bankası A.Ş." & 140,048 & 2.5 \\
\hline Total & $\mathbf{4 , 8 8 0 , 5 7 7}$ & $\mathbf{8 6 , 1}$ \\
\hline
\end{tabular}

Source: The Banks Association of Turkey

As shown in Table 1, total asset size of the 10 banks constitutes $86.1 \%$ of the Turkish banking sector by the end of 2020. These banks cover significant assets and market share in the banking industry. As industry, the sum of deposit banks and development/investment banks taken. 2010/1 ${ }^{\text {st }}$ quarter to $2020 / 4^{\text {th }}$ quarter data is used for all banks included in the analysis, so that balanced panel data is obtained.

\subsection{Methodology}

In this study, static panel data analysis is used. Panel data analysis basically comes up with 2 different models: Fixed-effect and random-effect models.

In fixed-effect model, differences between units are expressed via differences in fixed terms. In other words, the fixed parameters in the model vary from unit to unit, and the number of fixed terms occur proportionally to the number of cross sections. In the study, the units (cross sections) correspond to banks. In fixed effect model, the slope parameters $(\beta 1$ it $=\beta)$ are same for all cross section units and time.

In random effect model, it is assumed that the differences in the fixed term, which refers to the differences between each unit (cross section) can be random as if they are pulled from a bag and can be considered as part of the error term.

Liquidity risk is estimated to be a function of macroeconomic and bank-specific variables with the model:

$$
L R_{\mathrm{it}}=\alpha_{0}+\alpha_{1} \text { bank }_{\mathrm{i}, \mathrm{t}}+\alpha_{2} \text { macro }_{\mathrm{t}}+u_{\mathrm{t}}
$$

In model, $i$ refers to each commercial bank and $t$ is time. $L R_{i}$ is the dependent variable of the model and represents the liquidity risk calculated by ratio of liquid assets to short-term liabilities. The "bank" variable in the model shows 7 bank-specific variables, "macro" variable refers to 3 macroeconomic variables, and $u_{t}$ is the term error with a fixed average of zero variance.

Hypotheses of the study is as follows:

$\mathrm{H}_{1}$ : There is a relationship between Money Market Funds/Total Asset Variable and liquidity risk.

$\mathrm{H}_{2}$ : There is a relationship between Financial Assets at Fair Value Through Profit or Loss/Total Asset and liquidity risk.

The dependent and independent variables are presented in Table 3. 
Table 3. Variables Used in Model

\begin{tabular}{|c|c|}
\hline \multicolumn{2}{|l|}{$\begin{array}{l}\text { Dependent Variable } \\
\text { "Liquid Assets / Short-term Liabilities" }\end{array}$} \\
\hline \multicolumn{2}{|l|}{ Independent Variables } \\
\hline Bank-Specific Variables & Macroeconomic Variables \\
\hline "Asset Size (Share from sector)" & "Inflation" \\
\hline "Equity/ Total Assets" & "Average Deposit Interest Rate" \\
\hline "Total Deposits/ Total Assets" & "GDP Growth Rate" \\
\hline $\begin{array}{l}\text { "Non-Interest Income (net)/Other Operating } \\
\text { Income" }\end{array}$ & \\
\hline "Non-performing Loans /Total Loans" & \\
\hline "Money Market Funds/Total Assets" & \\
\hline $\begin{array}{l}\text { "Financial Assets at Fair Value Through Profit or } \\
\text { Loss/Total Assets" }\end{array}$ & \\
\hline
\end{tabular}

Bank-specific ratios are obtained from the statistical reports section of the Banks Association of Turkey website. The annual growth rate of GDP and Consumer Price Index (CPI) data are obtained from the official website of TURKSTAT. As interest rate, weighted average interest rates for deposits taken into account and obtained from "Electronic Data Delivery System (EVDS)" of Central Bank of the Republic of Turkey.

Period covering 2010-2020, it is aimed to investigate bank specific (internal) and macro indicators (external) that have an impact on the liquidity risk of the top 10 commercial banks according to their total assets in the Turkish banking sector. The variables in Table 3 are determined by examining domestic and foreign literature. Additionally, "Money Market Funds/Total Assets" and "Financial Assets at Fair Value Through Profit or Loss/Total Assets" variables are included in the model by us and are important in terms of the contribution of the study to the literature.

The following summary statistics show the maximum, minimum, average and standard deviation values of deposit banks.

Table 4. Descriptive Statistics

\begin{tabular}{|l|c|c|c|c|}
\hline Variable & Mean & Std. Deviation & Min & Max \\
\hline $\begin{array}{l}\text { "Liquid Assets / Short-term } \\
\text { Liabilities" }\end{array}$ & 41.9887 & 15.284 & 7.6 & 110.5806 \\
\hline $\begin{array}{l}\text { "Asset Size (Share from } \\
\text { sector)" }\end{array}$ & 8.5747 & 3.7934 & 1.8 & 16.64 \\
\hline
\end{tabular}




\begin{tabular}{|c|c|c|c|c|}
\hline "Equity/ Total Assets" & 10.8296 & 1.6975 & 6.3 & 15.60 \\
\hline "Total Deposits/ Total Assets" & 61.0708 & 5.3220 & 48.95 & 83.7 \\
\hline $\begin{array}{l}\text { "Non-Interest Income } \\
\text { (net)/Other Operating } \\
\text { Income" }\end{array}$ & 76.6945 & 45.4122 & -65.8 & 288.4 \\
\hline $\begin{array}{l}\text { "Non-performing Loans /Total } \\
\text { Loans" }\end{array}$ & 3.8493 & 1.7643 & 1.2 & 10.45 \\
\hline $\begin{array}{l}\text { "Money Market Funds/Total } \\
\text { Assets" }\end{array}$ & 6.2325 & 4.0258 & 0 & 16 \\
\hline $\begin{array}{l}\text { "Financial Assets at Fair } \\
\text { Value Through Profit or } \\
\text { Loss/Total Assets" }\end{array}$ & 1.0644 & 1.0550 & 0 & 6.27 \\
\hline "Inflation" & 10.1384 & 3.9558 & 3.99 & 24.52 \\
\hline $\begin{array}{l}\text { "Average Deposit Interest } \\
\text { Rate" }\end{array}$ & 11.4482 & 4.0467 & 6.65 & 23.21 \\
\hline "GDP Growth Rate" & 1.4299 & 3.2933 & -10.9760 & 15.9374 \\
\hline
\end{tabular}

\subsection{Test of Stationarity}

The first thing to consider in panel data analysis is the stationary of the variables. Time series often include trend or seasonality that can lead to non-stationary of the series (Yurdakul, 2003). If a model is predicted with non-stationary variable set using the ordinary least squares method, relationships between variables that do not actually exist leads to a spurious regression. For this reason, before estimating models unit root test is applied via Stata version 16.0.

Harris-Tzavalis (HT) unit root test is implemented to investigate the stationary of the series.

The unit root test hypotheses:

$\mathrm{H}_{0}=$ Series contains unit root (Non-stationary).

$\mathrm{H}_{1}=$ Series does not contain unit root (Stationary)

Unit root test is applied for each ratio. Table 5 presents the results of the Harris-Tzavalis unit root test.

Table 5. Harris-Tzvalis Unit Root Test Results

\begin{tabular}{|l|c|c|}
\hline Variables & $\begin{array}{c}\text { Statistical } \\
\text { Value }\end{array}$ & $\begin{array}{c}\text { Probability } \\
\text { Value }\end{array}$ \\
\hline "Liquid Assets / Short-term Liabilities" & 0.8871 & 0.0185 \\
\hline "Asset Size (Share from sector)" & 1.0184 & 0.9999 \\
\hline "Equity/ Total Assets" & 0.8585 & 0.0004 \\
\hline "Total Deposits/ Total Assets" & 0.8285 & 0.0000 \\
\hline "Non-Interest Income (net)/Other Operating Income" & 0.7798 & 0.0000 \\
\hline "Non-performing Loans /Total Loan" & 0.9571 & 0.8585 \\
\hline "Money Market Funds/Total Assets" & 0.8063 & 0.0000 \\
\hline "Financial Assets at Fair Value Through Profit or Loss/Total Assets" & 0.8187 & 0.0000 \\
\hline "Inflation" & 0.8095 & 0.0000 \\
\hline "Average Deposit Interest Rate" & 0.8648 & 0.0010 \\
\hline "GDP Growth Rate" & -0.3496 & 0.0000 \\
\hline
\end{tabular}


According to the HT test results, probability value of $<0.05$ variables found to be stationary and decided to be used in the analysis. Since probability value of two variables $>0.05$ determined not to be stable, $1^{\text {st }}$ degree difference of them were taken in order to get stationary.

After $1^{\text {st }}$ degree differences are taken, the results of the unit root test are shown in Table 6 .

Table 6. Unit Root Test Results After Difference

\begin{tabular}{|l|c|c|}
\hline Variables & $\begin{array}{c}\text { Statistical } \\
\text { Value }\end{array}$ & $\begin{array}{c}\text { Probability } \\
\text { Value }\end{array}$ \\
\hline "Asset Size (Share from sector)" & -0.0400 & 0.0000 \\
\hline "Non-performing Loans /Total Loans" & 0.1903 & 0.0000 \\
\hline
\end{tabular}

When the series examined in Table 6, probability values are less than 0.05 and series became stationary.

\subsection{Empirical Findings}

After all variables found to be stationary, panel data models are estimated. But before performing panel data analysis, unit effect test done whether unit effect exist or not.

Table 7. Unit Impact Testing

\begin{tabular}{|l|c|c|}
\hline & F Test & Probability Value \\
\hline Unit Impact Test & 6.52 & 0.0000 \\
\hline
\end{tabular}

From Table 7, the null hypothesis $\left(\mathrm{H}_{0}\right)$ which is unit effect equal to zero is rejected and concluded that unit effect exist. As a result of the F-Test, it is decided that data set is suitable to panel data regression. Then, fixed effect and random effect regressions done for panel data analysis. Finally, Hausman test used to select the appropriate model. In literature Hausman Test is used to decide whether the models will be estimated as fixed effect or random effect.

The Hausman test hypotheses:

$\mathrm{H}_{0}$ : Random effect model is efficient.

$\mathrm{H}_{1}$ : Fixed effect model is efficient.

The results of the Hausman Test is shown in Table 8.

Table 8. Hausman Test Results

\begin{tabular}{|l|c|c|}
\hline & Hausman Test $\left(\mathbf{X}^{2}\right)$ & Probability Value \\
\hline Random or Fixed Effect & 8.50 & 0.5805 \\
\hline
\end{tabular}

Because Hausman test statistics (p-value) is greater than 0.05 significance level, $\mathrm{H}_{0}$ (null) hypothesis could not be rejected. Therefore, random effect model is efficient. The estimated coefficients that fit best regression model for the entire period 2010-2020 are presented in Table 9. 
Table 9. Random Effect Model (Dependent Variable: Liquid Asset/ Short-term Liabilities)

\begin{tabular}{|l|l|l|l|}
\hline Variables & Coefficients & Z Statistics & Probability \\
\hline "Asset Size (Share from sector)" & -4.216 & -1.85 & $0.064^{*}$ \\
\hline "Equity/ Total Assets" & 1.652 & 3.65 & $0.000^{* * *}$ \\
\hline "Total Deposits/ Total Assets" & -0.100 & -0.65 & 0.515 \\
\hline "Non-Interest Income (net)/Other Operating Income" & -0.027 & -1.89 & $0.059^{*}$ \\
\hline "Non-performing Loans /Total Loans" & 1.934 & 1.42 & 0.157 \\
\hline "Money Market Funds/Total Assets" & 0.881 & 4.30 & $0.000^{* * *}$ \\
\hline "Financial Assets at Fair Value Through Profit Or Loss/Total Assets" & -0.593 & -1.01 & 0.312 \\
\hline "Inflation" & -1.551 & -6.00 & $0.000^{* * *}$ \\
\hline "Average Deposit Interest Rate" & -0.403 & -1.55 & 0.122 \\
\hline "GDP Growth Rate" & -0.014 & -0.09 & 0.928 \\
\hline Constant Term & 47.605 & 3.83 & $0.000^{* * *}$ \\
\hline Adjusted R': 0.4422 & & \\
$X^{2}$ Statistic: $326,37(0.0000)$ & & & \\
& & & \\
\hline
\end{tabular}

Note: $* * *, * *$ and $*$ signs show statistical significance at $1 \%, 5 \%$ and $10 \%$ levels

Concluding that random effects model is consistent, Breusch and Pagan Lagrangian Multiplier Test is used to check robustness of random effect model. Breusch and Pagan Lagrangian Multiplier test result is shown in Table 10.

Table 10. Breusch and Pagan Lagrangian Multiplier Test

\begin{tabular}{|l|c|c|}
\hline & Chibar $^{2}$ & Probability $^{2}$ \\
\hline Breusch Pagan LM Test for random effects & 38.09 & 0.00 \\
\hline
\end{tabular}

The Breusch and Pagan Lagrangian Multiplier test hypotheses:

$\mathrm{H}_{0}$ : Pooled OLS model is appropriate.

$\mathrm{H}_{1}$ : Random effect model is appropriate.

In Breusch and Pagan Lagrangian Multiplier test results the variance for $u$ is 0 and the $p$ value is 0 which means null hypothesis rejected and random effect model is appropiate.

Considering Table 9, about bank-specific variables the relationship between Equity/Total Assets and Liquid Assets/ Short-Term Liabilities is significantly positive. As Equity/Total Assets ratio increases Liquid Assets/ Short-Term Liabilities ratio simultaneously increases. The increase in the ratio of Liquid Assets/Short Term Liabilities indicates that the risk of liquidity is reduced. In other words, increasing bank capital leads to a decrease in liquidity risk. Higher capital reduces liquidity risk is relevant with the "financial fragility-crowding out hypothesis". Under "financial fragility-crowding out" hypothesis, banks with strong capital structure crowd out deposits and accordingly liquidity creation is reduced. Banks create liquidity by financing illiquid assets with liquid liabilities, thus capital reduces liquidity creation by excluding deposits which are liquid liabilities. As level of liquidity creation decreases, liquidity risk that bank may be exposed to decreases (Berger \& Bouwman, 2009).

Rrelationship between Money Market Funds/Total Assets and Liquid Assets/ Short-Term Liabilities is also significantly positive. As Money Market Funds/Total Assets ratio increases Liquid 
Assets/ Short-Term Liabilities ratio simultaneously increases. The increase in the ratio of Liquid Assets/Short Term Liabilities indicates that the risk of liquidity is reduced. The relationship between money market funds and liquidity risk is negative; meaning that increase in in the level of money market funds in balance sheet decreases the liquidity risk that the bank may be exposed to. Money market funds are funds provided through the Central Bank of the Republic of Turkey (CBRT) and Incorporation of Istanbul Settlement and Custody Bank Inc (Takasbank). The deposit facility and repo transactions used via CBRT is accounted in the "Money Market Funds" and these funds are important sources for banks. The ability of banks to provide additional liquidity with standing facilities in both CBRT and other money markets, and the ability to borrow easily from short-term markets increases the capacity to provide liquidity, decreasing liquidity risk level.

About macroeconomic variables, the relationship between inflation (CPI) and Liquid Assets/Short-Term Liabilities ratio is significantly negative. It can be said that the increase in inflation disrupts overall macroeconomic balance and increasing instability. For this reason, fragility of the banking sector increases and probability of exposure to crises and in particular liquidity risk increases.

\section{CONCLUSION}

Bank's liquidity structures are very important both in terms of the performance of the banks and the healthy functioning of the economic system. 2000/November, 2001/February crises in Turkey and 2008 global economic crisis once again demonstrated the importance of liquidity risk and showed that liquidity could lead banks to bankruptcy.

In study, factors affecting liquidity risk of deposit banks in Turkey are examined. According to the 2020 annual financial reports, top 10 banks with highest asset size is included in the sample. Quarterly data from 2010 to 2020 tested with static panel data analysis in the study. Total of 10 different variables are used, 7 of which are bank-specific and 3 macroeconomic, that can affect the liquidity risk of banks.

As a result of the analysis, among the independent variables "Equity/Total Asset", "Money Market Funds/Total Assets" and "Inflation" are significant at the confidence level of 5\%.

According to the results, Equity/Total Assets and the Liquid Assets/Short Term Liabilities are positively correlated. Therefore, it can be said that deposit banks in Turkey can increase their capital in order to manage liquidity risk effectively. Secondly, there is a positive relationship between Money Market Funds/Total Assets and Liquid Assets/Short-Term Liabilities. Banks' potential to obtain additional liquidity from money markets has a mitigating effect on liquidity risk. Finally, given that the banking sector is affected from macroeconomic variables, increase of inflation also increases the liquidity risk that banks may face. 
The negative relationship between capital and liquidity risk coincides with the findings of Dinger (2009), Vodová (2011), Laurine (2013) and Işık and Belke (2017). Another negative relationship between inflation and liquidity risk coincides with the results of Laurine (2013), Ayaydin and Karaaslan (2014), Singh and Sharma (2016), but differ from the findings of Vodová (2011) and Zengin and Yüksel (2016).

The contribution of this study is to use Money Market Funds/Total Assets ratio to investigate the causes of liquidity risk. Besides, we find that Money Market Funds/Total Assets is an endogenous determinant of liquidity risk. Thus, it has been demonstrated that banks with the possibility of providing more funds from money markets may be exposed to relatively lower liquidity risk. As a result, banks can increase their profitability by managing liquidity risk correctly with taking these factors into account.

\section{REFERENCES}

Ahamed, F. (2021). Determinants of Liquidity Risk in the Commercial Banks in Bangladesh. European Journal of Business and Management Research, 6(1), 164-169.

Akhtar M.F, K. Ali and S. Sadaqat (2011), Liquidity Risk Management: A Comparative Study Between Conventional And Islamic Banks Of Pakistan. Interdisciplinary Journal Of Research in Business, 1(1), 35-44.

Altıntaş M. A (2018). Bankacılıkta Risk ve Sermaye Yönetimi [Adobe Digital Editions]. Access adress: Google Books.

Altıntaş, M. A. (2006). Bankacılıkta Risk Yönetimi ve Sermaye Yeterliliği: 5411 Sayılı Bankacılık Kanunu, Basel-I ve Basel-II Çerçevesinde. Turhan Kitabevi.

Ayaydın, H. and Karaaslan, İ. (2014). Likidite Riski Yönetimi: Türk Bankacılık Sektörü Üzerine Bir Araștırma. Gümüşhane Üniversitesi Sosyal Bilimler Enstitüsü Elektronik Dergisi, $5(11)$.

Berger, A. N., and Bouwman, C. H. (2006). The measurement of bank liquidity creation and the effect of capital. SSRN 672784.

Berger, A. N., and Bouwman, C. H. (2009). Bank liquidity creation. The review of financial studies, 22(9), 3779-3837.

BRSA, Regulation On Calculation Of Liquidity Coverage Ratio Of Banks. Turkey-Legal Gazette (28948, 21 March 2014).

BRSA, Regulation on Measurement and Evaluation of Liquidity Adequacy of Banks. TurkeyLegal Gazette (26333, 1 November 2006).

BRSA, Guideline For Liquidity Risk Management, 31 March 2016.

Candan, H. and Özün, A. (2009). Bankalarda Risk Yönetimi ve Basel II. 2.Baskı, İstanbul: Türkiye İş Bankası Kültür Yayınları.

Çanakcı, M. and Tunalı, H. (2018). İslami Bankacılık Sektöründe Likidite Riski Unsurlarını Belirleyen Esaslar. Akademik Araştırmalar ve Çalışmalar Dergisi (AKAD), 10(18), 90119. 
Çelik, S. and Akarım, Y. D. (2012). Likidite Riski Yönetimi: Panel Veri Analizi ile İMKB Bankacıl1k Sektörü Üzerine Ampirik Bir Uygulama. Eskişehir Osmangazi Üniversitesi Sosyal Bilimler Dergisi, 13(1).

Dinger, V. (2009). Do Foreign-Owned Banks Affect Banking System Liquidity Risk? Journal Of Comparative Economics 37(4): 647-657.

Erdem, E. and Torun, T. (2018). Türkiye'deki Ticari Bankaların Likidite Riski Düzeylerinin Kümeleme Analizi ile Belirlenmesi. Current Debates on Social Sciences Human Studies 3, 316.

Firuzan, E. and Firuzan, A. R. (2017). Türk Bankalarının Likidite ve Kredi Risk Değerlendirmesi: Dinamik Panel Veri Analizi. Business and Management Studies: An International Journal, 5(3), 703-716.

Işık, Ö. and Belke, M. (2017). Likidite Riskinin Belirleyicileri: Borsa İstanbul'a Kote Mevduat Bankalarından Kanıtlar. Ekonomi, Politika and Finans Araştırmaları Dergisi, 2(2), 113-126.

Işı1, G. and Özkan, N. (2015). İslami Bankalarda Likidite Riski Yönetimi: Türkiye'de Katılım Bankacıllı̆̆1 Üzerine Ampirik Bir Uygulama. International Journal of Islamic Economics and Finance Studies, 1(2), 23-37.

Laurine, C. (2013). Zimbabwean commercial banks liquidity risk determinants after dollarisation. Journal of Applied Finance and Banking, 3(6), 97.

Moussa, M. A. B. (2015). The Determinants Of Bank Liquidity: Case Of Tunisia. International Journal Of Economics And Financial Issues 5(1): 249-259

Munteanu, I. (2012). Bank liquidity and its determinants in Romania. Procedia Economics and Finance, 3, 993-998.

Reddy, Y. V. (2002). A Short Term Liquidity Forecasting Model For India. Reserve Bank Of India.

Shen, C.-H., Kuo, C.-J., and Chen, H.-J. (2001). Determinants Of Net Interest Margins İn Taiwan Banking Industry. Journal Of Financial Studies, 9, 47-83.

Singh, A., and Sharma, A. K. (2016). An empirical analysis of macroeconomic and bankspecific factors affecting liquidity of Indian banks. Future Business Journal, 2(1), 4053.

Sopan, J., and Dutta, A. (2018). Determinants of liquidity risk in Indian banks: A panel data analysis. Asian Journal of Research in Banking and Finance, 8(6), 47-59.

Şakar, H. (2002). Risk Yönetimi Açısından Bankalarda Aktif Pasif Yönetimi. MIDA Institute.

Vodova, P. (2013). Determinants Of Commercial Bank Liquidity İn Hungary. E-Finanse 9(3): 64-71.

Yurdakul, F. (2003).Yapısal Kırılmaların Varlı̆̆ı Durumunda Gelişstirilen Birim-Kök Testleri Ekonometri Seçme Yazllar (Editörler Aydın Ünsal-Nezri Köse). Ankara: Gazi Üniversitesi Iibf Gel. Vakfi İşletmesi.

Zengin, S. and Yüksel, S. (2016). Likidite Riskini Etkileyen Faktörler: Türk Bankacilık Sektörü Üzerine Bir İnceleme. İstanbul Ticaret Üniversitesi Sosyal Bilimler Dergisi, 29(2), 7795. 